\title{
Penentuan Harga dengan Menggunakan Sistem Inferensi Fuzzy Tsukamoto Pada Rancang Bangun Aplikasi "Finding-Tutor"
}

\author{
Syah Dia Putri Mustika Sari, R.V. Hari Ginardi, dan Chastine Fatichah \\ Departemen Teknik Informatika, Fakultas Teknologi Informasi, Institut Teknologi Sepuluh Nopember \\ (ITS) \\ e-mail: hari@if.its.ac.id
}

\begin{abstract}
Abstrak-Keterbatasan waktu yang dimiliki di sekolah membuat kegiatan belajar tidak hanya berlangsung di dalam ruang kelas saja. Orang tua juga tidak dapat kita libatkan secara maksimal dalam kegiatan belajar karena keterbatasan waktu dan kemampuan materi yang dikuasai. Hal ini menjadikan tutor sebagai salah satu profesi yang cukup dibutuhkan dan menjanjikan. Namun, keterbatasan waktu dan lokasi membuat tutor kesulitan menemukan konsumen yang sesuai. Selain itu, kendala utama yang dihadapi konsumen adalah ketetapan harga tutor yang cukup mahal. Studi ini ditujukkan untuk mengatasi masalah tersebut dengan sebuah aplikasi berbasis Android yang dapat membantu konsumen mencari tutor. Aplikasi tersebut dilengkapi dengan sebuah sistem pendukung keputusan yang dapat membantu menghitung harga layanan dengan Sistem Inferensi Fuzzy Tsukamoto. Hal ini memungkinkan system menghitung harga layanan dengan tepat berdasarkan dengan kriteria tertentu. Hasil dari penelitian ini adalah berupa aplikasi pencarian tutor yang dilengkapi dengan Sistem Inferensi Fuzzy Tsukamoto yang menghitung harga layanan berdasarkan tingkat kesulitan, waktu dan jarak.
\end{abstract}

Kata Kunci-Fuzzy Inference System, Fuzzy Tsukamoto, Android.

\section{PENDAHULUAN}

$\mathrm{P}$ ADA saat ini permintaan guru les privat (tutor) sudah semakin besar dan akan terus bertambah. Namun, masyarakat harus tetap jeli dalam memilih tutor yang aman dengan harga yang bersaing. Banyaknya kriteria yang menentukan kualitas keamanan tutor membuat harga yang ditawarkan sangat bervariatif. Maka dari itu, masyarakat membutuhkan sebuah wadah yang dapat memudahkan dalam mendapatkan guru tutor sesuai dengan keahlian yang dibutuhkan serta keamanan dan harga yang bersaing.

Seiring dengan perkembangan teknologi saat ini, adanya sebuah aplikasi yang merupakan teknologi yang sedang berkembang pesat pada saat ini dapat menjadi solusi dari permasalahan tersebut. Maka dari itu aplikasi E-Commerce berbasis perangkat bergerak (mobile) yang diberi nama "Finding-Tutor" akan dibuat.

Aplikasi ini dapat memudahkan masyarakat untuk mendapatkan tutor yang sesuai kebutuhan dan waktu dengan harga yang bersaing. Harga yang bersaing dapat digunakan developer untuk menarik masyarakat sebagai konsumen untuk menggunakan aplikasi ini. Output dari metode yang digunakan berupa harga yang merepresentasikan hasil dari perhitungan sistem dengan metode Fuzzy Tsukamoto. Untuk mendapatkan harga final yang akan digunakan maka data tersebut akan diolah kembali dengan masukan konsumen berupa durasi dan ketentuan zona-zona daerah yang sudah ditetapkan sebelumnya untuk menjadi harga yang menarik dan tetap menguntungkan untuk kedua belah pihak.

\section{LITERATUR PENELITIAN}

\section{A. E-Commerce}

Bisnis yang berkembang pada saat ini lebih banyak memanfaatkan konsep e-business. E-business merupakan penggunaan kombinasi dari teknologi internet dan teknologi lain untuk bekerja dan mendukung proses bisnis yang ada pada suatu perusahaan.[1] Seiring dengan adanya perkembangan teknologi dan penggunaan konsep $e$-business pada saat ini, banyak perusahaan yang telah menerapkan konsep dari $e$ commerce dalam proses bisnis yang ada pada perusahaan.

E-commerce adalah suatu bentuk perubahan persaingan dalam seluruh proses interaksi bisnis seperti pemasaran, penjualan, pengiriman, pembayaran dan layanan pada transaksi global yang saling terkait.[1]. Terdapat 4 kategori dasar pada aplikasi layanan E-Commerce yaitu Business-to-Consumer (B2C), Business-to-Business (B2B), Consumer-to-Consumer (C2C) dan Business-to-Government (B2G).[1] Keuntungan yang didapatkan dari kesuksesan penerapan konsep $e$ commerce adalah memungkinkan berbagai proses bisnis yang ada pada perusahaan untuk dilakukan dimanapun, kapanpun dan dengan siapa saja secara lebih efisien.

\section{B. Artificial Intelligence}

Seiring banyaknya penerapan $e$-commerce pada perusahaan bisnis, teknologi Artificial Inteligence (AI) sering digunakan untuk mendukung maupun memperbaiki dukungan keputusan perusahaan. Salah satu tujuan dari teknologi AI adalah untuk meduplikat kemampuan manusia untuk berfikir, melihat, mendengar, berjalan, berbicara dan merasakan pada sebuah komputer yang akan dikembangkan.[1]

Aplikasi Artificial Inteligence (AI) memiliki 3 domain utama yaitu Cognitive Science, Robotics, dan Natural Interfaces.[1] Salah satu aplikasi AI yang diterapkan secara luas dalam bisnis adalah pengembangan sistem pakar (Expert System). Sistem pakar (Expert System) merupakan sistem informasi berbasis 
pengetahuan yang menggunakan pengetahuan tersebut pada aplikasi dan bertindak sebagai konsultan ahli bagi end user.[1] Terdapat 4 cara yang dapat digunakan untuk merepresentasikan pengetahuan ke dalam basis pengetahuan sistem pakar yaitu Case-Based Reasoning, Frame-Based Knowledge, ObjectBased Knowledge dan Rule-Based Knowledge dimana pengetahuan direpresentasikan dalam bentuk aturan dan pernyataan fakta.[1]

\section{Inference system Fuzzy}

Sistem Inferemsi Fuzzy merupakan metode penalaran yang menyerupai penalaran manusia yang memungkinkan untuk memperkirakan nilai maupun kesimpulan dari data yang tidak lengkap atau data ambigu tanpa hanya mengandalkan crisp data, seperti yang terjadi pada data biner yang berisikan pilihan Iya/Tidak[1] Ilustrasi inference system Fuzzy dapat ditunjukkan pada Gambar 1.

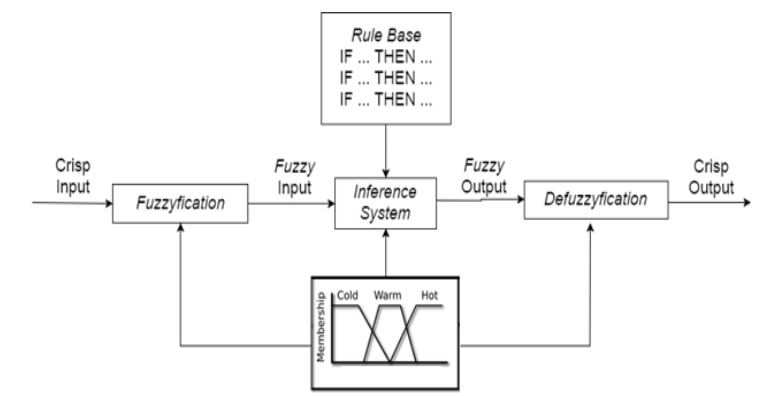

Gambar 1. Ilustrasi Inference system Fuzzy

\section{1) Variabel Fuzzy}

Variabel Fuzzy merupakan variabel yang akan dibahas dalam suatu sistem Fuzzy. Pada variabel yang digunakan pada sistem Fuzzy menggunakan konsep variabel linguistik.[2] Variabel linguistik merupakan variabel yang memiliki nilai berupa kata/kalimat.

\section{2) Semesta Pembicaraan}

Semesta pembicaraan adalah keseluruhan nilai yang diperbolehkan untuk dioperasikan dalam suatu variabel Fuzzy. Nilai semesta pembicaraan dapat berupa bilangan positif maupun negatif yang merupakan atribut numeris dari suatu variabel.

\section{3) Membership function}

Membership function adalah grafik yang mewakili besar dari derajat keanggotaan masing-masing variabel input yang berada dalam interval 0 dan 1 . Salah satu cara untuk mendapatkan nilai keanggotaan adalah dengan menggunakan pendekatan fungsi.[3] Beberapa membership function yang dapat digunakan antara lain :

\section{a) Membership function Linear Naik dan Turun}

Membership function linear naik maupun turun memiliki parameter $\mathrm{a}$ dan $\mathrm{b}$. Untuk persamaan membership function linear naik dapat ditunjukkan pada persamaan (2.1) seperti berikut:

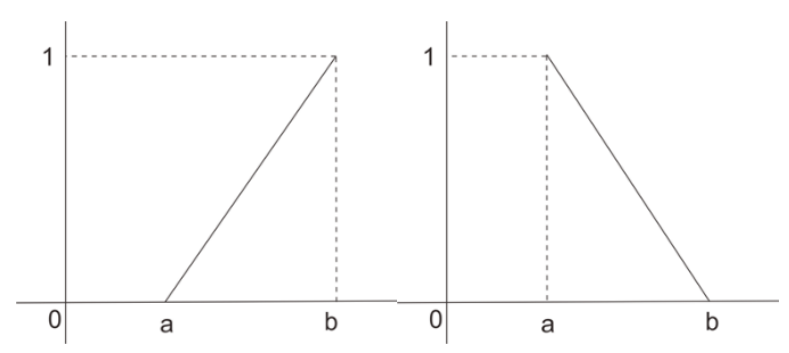

Gambar 2. Representasi Membership function Linear Naik dan Turun

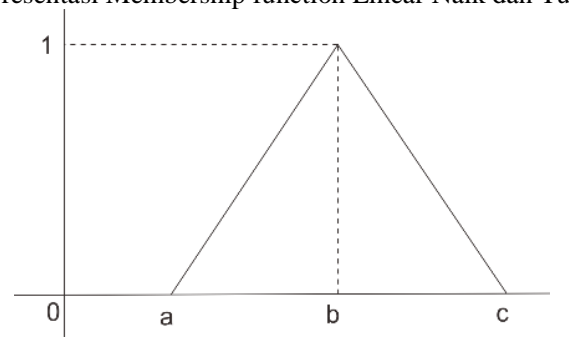

Gambar 3. Representasi Membership function Segitiga

$$
\mu(x ; a, b)=\left\{\begin{aligned}
0, & x<a \\
\frac{x-a}{b-a}, & a \leq x \leq b \\
1, & x>b
\end{aligned}\right.
$$

Untuk persamaan membership function linear turun dapat ditunjukkan pada persamaan (2.2) seperti berikut:

$$
\mu(x ; a, b)=\left\{\begin{array}{cl}
1, & x<a \\
\frac{b-x}{b-a}, & a \leq x \leq b \\
0, & x>b
\end{array}\right.
$$

Representasi grafik dari persamaan (1) dan (2) dapat ditunjukkan pada Gambar 2.

\section{b) Membership function Segitiga}

Membership function segitiga memiliki parameter $a, b, c$ dengan persamaan membership function segitiga yang ditunjukkan pada persamaan (3) seperti berikut:[4]

$$
\mu(x ; a, b, c)=\left\{\begin{array}{cl}
0, & x<a \\
\frac{x-a}{b-a}, & a \leq x \leq b \\
\frac{c-x}{c-b}, & b<x \leq c \\
1, & x>c
\end{array}\right.
$$

Representasi grafik dari persamaan (2.3) dapat ditunjukkan pada Gambar 4.

\section{4) Himpunan Fuzzy}

Himpunan Fuzzy merupakan suatu kelompok yang mewakili suatu keadaan tertentu dalam suatu variabel Fuzzy. Setelah membentuk membership function dari himpunan Fuzzy yang telah ditentukan dapat dilakukan proses perhitungan derajat keanggotaan individu tersebut dalam himpunan Fuzzy.

\section{5) Operasi Himpunan Fuzzy}

Himpunan Fuzzy dapat dioperasikan seperti himpunan konvesional lainnya. Hasil dari operasi himpunan fuzzy dapat disebut juga sebagai $\alpha$-predikat. Himpunan fuzzy memiliki 3 operator yaitu Operator $A N D$, Operator $O R$ dan Operator NOT 6) Fuzzyfication

Fuzzyfication (tahap pengaburan) merupakan tahap pemetaan nilai masukan berupa nilai tegas (crisp data) yang diubah ke dalam bentuk nilai masukan fuzzy yang berupa derajat keanggotaan atau tingkat kebenaran.[5] 


\section{7) Inference system}

Tahap kedua pada metode Fuzzy yaitu inference system. Pada tahap ini telah dilakukan pembentukan basis pengetahuan fuzzy (Rule) yang akan digunakan untuk tahap evaluasi masukan yang telah diubah menjadi derajat keanggotaan fuzzy terhadap aturan atau rule fuzzy untuk menghasilkan output dari tiap-tiap rule yang telah dibangun di dalam sistem.

8) Defuzzyfication

Defuzzyfication (tahap penegasan) merupakan tahap dimana dilakukan transformasi hasil dari penarikan kesimpulan pada inference system menjadi output berupa nilai crisp atau nilai tegas. Terdapat 7 metode yang dapat digunakan dalam proses defuzzyfication antara lain yaitu Height Method, Centroid (Center of Gravity) Method, Weighted Average Method, MeanMax, Center of Sums, Center of Largest Area, First (or last) of Maxima.[3]

\section{9) Metode Tsukamoto}

Pada proses sistem inferensi metode Tsukamoto juga hanya menggunakan 1 operator yaitu operator AND (MIN) dengan cara mengambil nilai minimum pada himpunan fuzzy. Output fuzzy pada metode Tsukamoto berbentuk rentan keluaran harga dengan fungsi keanggotaan. Proses defuzzyfication pada metode ini menggunakan Weighted Average Method atau metode rata-rata terbobot, rumus yang digunakan pada metode tersebut adalah sebagai berikut :[5]

$$
Z=\frac{\sum\left(a_{\_} p_{i} z_{i}\right)}{\sum \alpha_{-} p_{i}}
$$

Keterangan :

$Z \quad=$ Hasil Defuzzyfication metode rata-rata terbobot

$a_{-} p_{i}=$ Nilai minimum derajat keanggotaan

$z_{i} \quad=$ Nilai crisp hasil inferensi rule

$i \quad=$ Jumlah aturan fuzzy

\section{PERANCANGAN SISTEM}

\section{A. Memodelkan Input}

Input yang akan digunakan dalam perhitungan harga tutor menggunakan metode Fuzzy Tsukamoto adalah tingkat kesulitan, waktu dan jarak antara tutor dengan konsumen (murid). Input tersebut merupakan hal-hal yang mempengaruhi harga dalam penentuan harga tutor yang didapatkan dari hasil kuisioner di lapangan. Input yang telah dimodelkan pada fungsi keanggotaan dapat ditunjukkan pada Gambar 4, Gambar 5 dan Gambar 6.

\section{B. Memodelkan Output}

Hasil dari perhitungan harga tutor pada metode Fuzzy Tsukamoto berupa harga yang dibangun dalam sebuah membership function pada Gambar 7. Keterangan output berupa harga ditunjukkan pada Tabel 1.

Tabel 1.

Kategori Harga Durasi 90 Menit

\begin{tabular}{cc}
\hline \hline Harga & Keterangan \\
\hline Rp 35.000 - Rp 60.000 & Murah \\
Rp 45.000 - Rp 80.000 & Sedang \\
$\operatorname{Rp~80.000-Rp~100.000~}$ & Mahal \\
\hline \hline
\end{tabular}

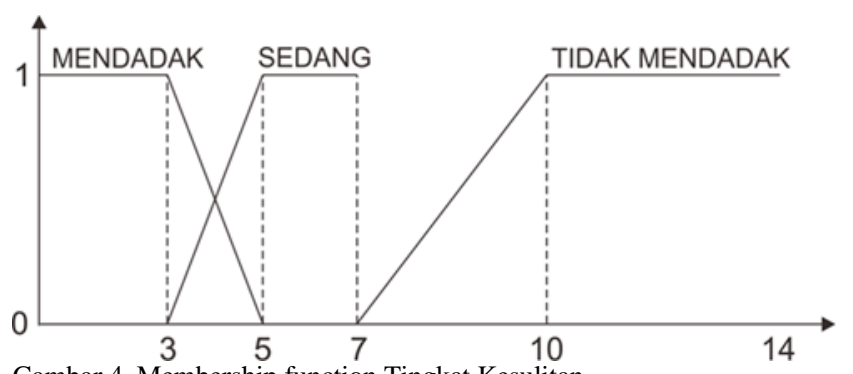

Gambar 4. Membership function Tingkat Kesulitan

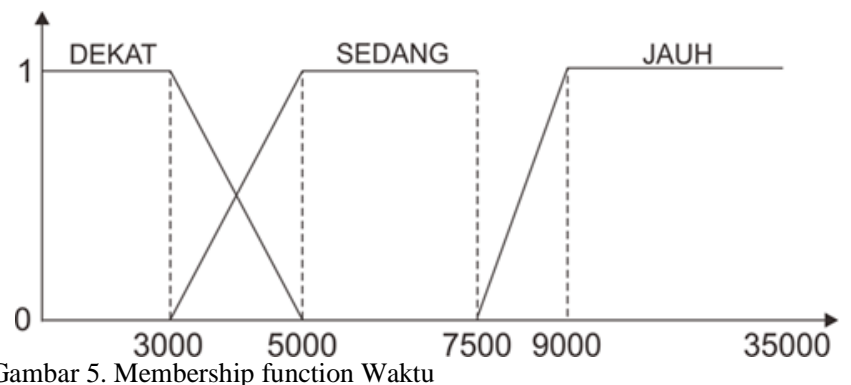

Gambar 5. Membership function Waktu
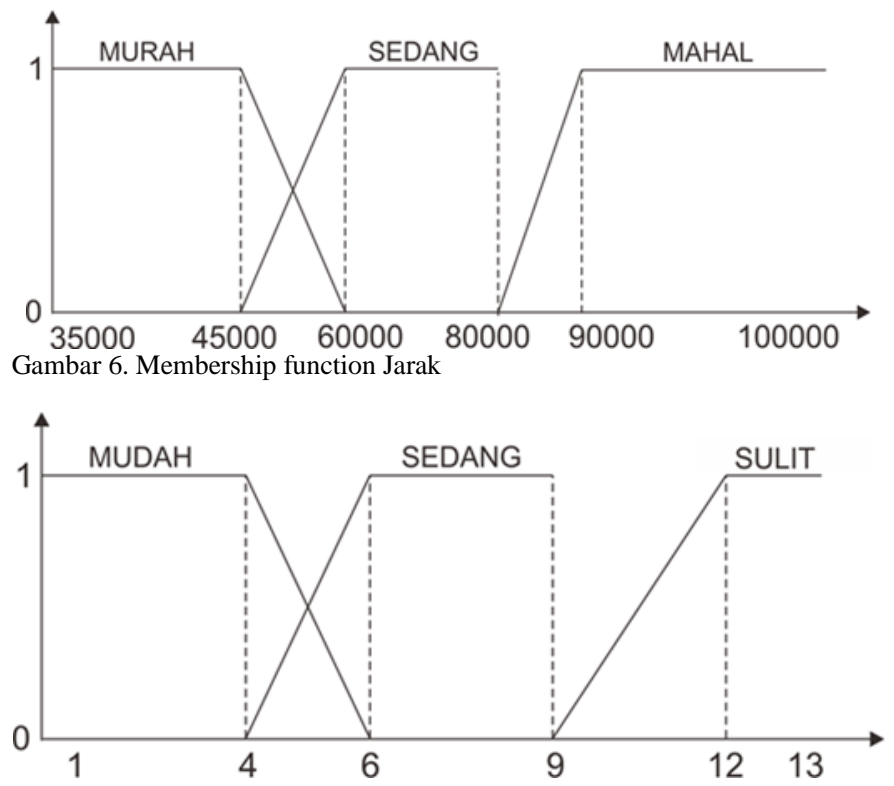

Gambar 7. Membership function Harga

\section{Implementasi Biaya Operasional Pada Perhitungan Harga}

Proses yang ada pada sistem akan mengolah data yang ada untuk mendapatkan harga akhir tutor yang akan digunakan pada aplikasi dengan menggunakan metode Fuzzy Tsukamoto. Karena luasnya daerah jangkauan aplikasi yaitu daerah Surabaya, maka dibutuhkan pembagian daerah yang ada di kota Surabaya menjadi 3 zona untuk menentukan tambahan biaya transportasi yang akan diberikan pada tutor. Nama zona dan ketentuan yang ditetapkan dapat dilihat pada Tabel 2.

Tabel 2.

Daftar Zona Daerah

\begin{tabular}{ccc}
\hline \hline & Deskripsi & Ketentuan \\
\hline Zona 1 & $5 \mathrm{~km}<$ Jarak $\leq 10 \mathrm{~km}$ & Harga + Rp 5.000 \\
Zona 2 & $10,1 \mathrm{~m}<$ Jarak $\leq 15 \mathrm{~km}$ & Harga + Rp Rp 10.000 \\
Zona 3 & Jarak $>15.001 \mathrm{~m}$ & Harga + Rp Rp 20.000 \\
\hline \hline
\end{tabular}




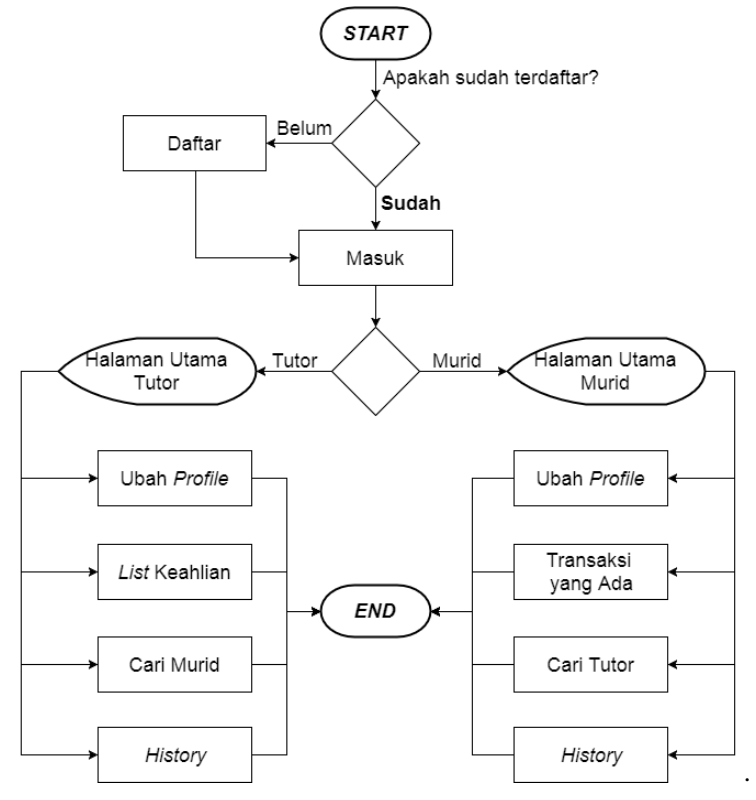

Gambar 8. Desain Umum Sistem

\section{Desain Umum Sistem}

Desain umum sistem pada aplikasi "Finding-Tutor" secara keseluruhan ditunjukan pada Gambar 8.

\section{IMPLEMENTASI}

\section{A. Implementasi Persiapan Masukan Sistem Fuzzy}

Terdapat 3 masukan user yang akan digunakan pada sistem yaitu tingkat kesulitan, waktu dan jarak. Masukan tingkat kesulitan yang dimasukkan user berupa tingkat pendidikan pada umumnya, sehingga masukan tersebut harus diubah menjadi nilai untuk tiap-tiap tingkatan pendidikan. Masukan user waktu berupa tanggal dimana transaksi mengajar akan dilakukan, sehingga harus dilakukan perhitungan selisih tanggal transaksi tersebut dengan tanggal yang ada pada sistem. Masukan jarak berupa jarak diantara alamat tutor dan murid. Langkah pertama adalah menggunakan Geocoder. Kemudian sistem akan melakukan request terhadap Google API dengan key yang telah didaftarkan sebelumnya.

\section{B. Implementasi Membership Function}

Membership function akan diimplementasikan untuk mendukung proses fuzzyfikasi. Batas-batas seperti semesta pembicaraan dan domain yang telah ditentukan sebelumnya akan diimplementasikan pada masing-masing ketentuan pada membership function yang akan dibangun.

\section{Implementasi Fuzzyfication dan Inference System}

Proses fuzzyfication dilakukan pada tiap-tiap aturan (rule) yang telah dibangun pada sistem. Pada proses fuzzyfication dalam perhitungan harga terdapat 27 aturan (rule) yang dibangun ke dalam sistem. Jumlah aturan tersebut didapatkan dari hasil perhitungan Jumlah_Domain ${ }^{\text {Jumlah_Variabel. Pada }}$ proses ini akan diterapkan fungsi matematika MIN.

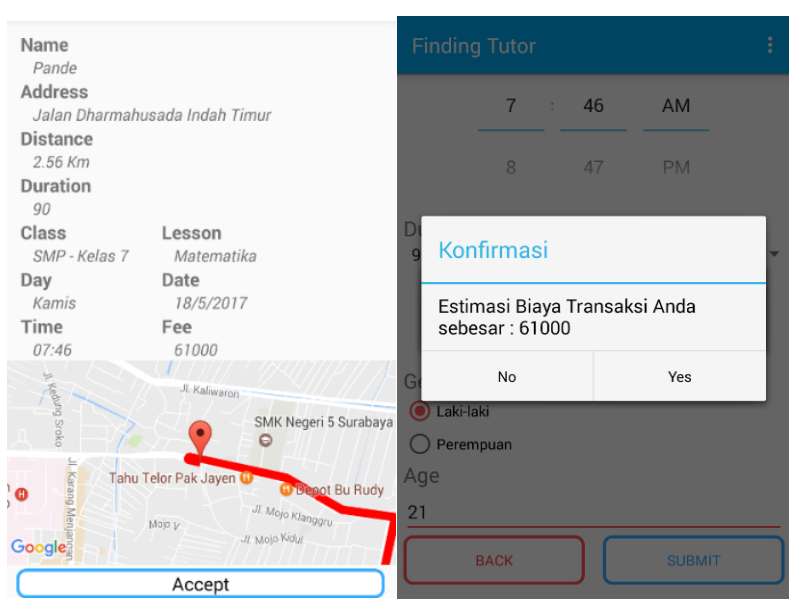

(a)

(b)

Gambar 12 Tampilan (a) Estimasi Harga (b) Harga Akhir

\section{Implementasi Defuzzyfication}

Proses defuzzyfication akan dilakukan pada fungsi defuzzyfication(). Pada fungsi ini akan dilakukan penjumlahan hasil dari perhitungan fungsi hitungX () berupa nilai minimum dari derajat keanggotaan yang dikalikan dengan nilai crisp hasil perhitungan fungsi hitungY(). Kemudian hasil penjumlahan dari perhitungan tersebut akan dibagi dengan jumlah nilai dari nilai minimum derajat keanggotaan pada fungsi hitungX ().

\section{E. Implementasi Perhitungan Harga Akhir}

Hasil dari defuzzyfikasi untuk mendapatkan harga awalakan dihitung berdasarkan dengan durasi user. Setelah itu jarak dari transaksi tersebut akan dicocokkan pada 3 zona daerah untuk mengetahui tambahan biaya transportasi yang akan ditambahkan pada harga awal. Harga akhir merupakan harga awal hasil defuzzyfikasi yang telah disesuaikan dengan durasi dan ditambah dengan biaya transportasi berdasarkan letak jarak pada 3 zona yang telah ditentukan sebelumnya.

\section{KESIMPULAN}

Berdasarkan hasil studi yang telah dilakukan, dapat diambil beberapa kesimpulan sebagai berikut:

a. Inference system Fuzzy Tsukamoto berhasil diimplementasi pada proses perhitungan estimasi harga dan perhitungan harga akhir untuk aplikasi "FindingTutor" dengan akurasi masing-masing sebesar $88,9 \%$ dan $92,6 \%$.

b. Inference system Fuzzy (FIS) Tsukamoto dapat menentukan jumlah harga sesuai dengan kriteria yang telah ditentukan yaitu tingkat kesulitan, waktu dan jarak.

c. Inference system Fuzzy (FIS) Tsukamoto dapat menentukan jumlah harga dengan mempertimbangkan fee transportasi dan keadaan waktu diantara 2 pengguna.

d. Inference system Fuzzy (FIS) Tsukamoto dapat menentukan jumlah harga sesuai dengan keadaan pasar saat ini. 


\section{DAFTAR PUSTAKA}

[1] J. O'Brien and G. Marakas, Management Information Systems, 10 edition. New York: McGraw-Hill Education, 2010.

[2] T. J. Ross, Fuzzy Logic with Engineering Applications, Third Edition, 3 edition. Chichester, U.K: Wiley, 2010.

[3] Fanoeel Thamrin, "STUDI INFERENSI FUZZY TSUKAMOTO UNTUK PENENTUAN FAKTOR PEMBEBANAN TRAFO PLN," UNIVERSITAS DIPONEGORO, SEMARANG, 2012.

[4] Diana Purwitasari, "Fuzzy Inference System (FIS)," Surabaya, Sep2016.

[5] I. Wahyuni, W. F. Mahmudy, and A. Iriany, "Rainfall prediction in Tengger region Indonesia using Tsukamoto fuzzy inference system," in 2016 1st International Conference on Information Technology, Information Systems and Electrical Engineering (ICITISEE), 2016, pp. 130-135.

[6] “Java," Wikipedia bahasa Indonesia, ensiklopedia bebas. 28-Jun-2016.

[7] "NetBeans IDE - Overview." [Online]. Available: https://netbeans.org/features/. [Accessed: 08-May-2017].

[8] "Mengenal Android Studio | Android Studio." [Online]. Available: https://developer.android.com/studio/intro/index.html. [Accessed: 08May-2017]. 